\title{
Pituitary and ovarian factors associated with seasonal quiescence of the tammar wallaby, Macropus eugenii
}

\author{
C. H. Tyndale-Biscoe and J. P. Hearn* \\ Division of Wildlife Research, CSIRO, P.O. Box 84, Lyneham, A.C.T., A ustralia 2602, and \\ *Institute of Zoology, the Zoological Society, Regents Park, London NW1 4RY, U.K.
}

\begin{abstract}
Summary. The role of the corpus luteum, the ovarian interstitial tissue and the ovarian cortex in the maintenance of the diapausing embryo was investigated by selective excision of the component tissues from female tammars undergoing seasonal quiescence. The response of the pituitary was assessed by measuring $\mathrm{LH}$ in peripheral plasma. No part of the ovary was necessary for the continued survival of the blastocyst in diapause for up to 4 months after ovariectomy, but at 8 months no blastocyst reactivated normally when the mother was treated with progesterone. Reactivation and the normal progress of pregnancy occurred in females deprived of the quiescent CL or the interstitial tissue only if a luteinized follicle or corpus luteum developed in the remaining ovary or a graft of ovarian cortical tissue. Plasma LH became elevated in bilaterally ovariectomized females, but not in unilaterally ovariectomized females or those carrying grafts of ovarian cortex.
\end{abstract}

\section{Introduction}

The tammar wallaby (Macropus eugenii) is unusual among the macropodid marsupials in that the corpus luteum of post-partum ovulation formed in January or February in the southern hemisphere remains quiescent and the blastocyst in diapause for several months after the end of lactation in October. Reactivation of the corpus luteum and blastocyst occurs synchronously in all adult females after the summer solstice in December (Berger, 1966; Renfree \& Tyndale-Biscoe, 1973; Sadleir \& Tyndale-Biscoe, 1977). By contrast, the corpus luteum of another seasonally breeding wallaby, the island dwelling quokka (Setonix brachyurus), involutes after lactation ceases in September, the blastocyst degenerates and the animal enters a true anoestrus (Sharman, 1955; Sharman \& Berger, 1969). Interstitial tissue is a prominent component of the tammar ovary at all times (Renfree \& Tyndale-Biscoe, 1973), whereas it is absent from the quokka ovary.

From these observations we postulated that the corpus luteum or the interstitial tissue separately or together may be responsible for the maintenance of quiescence and the prolonged survival of the blastocyst in the tammar. We have tested this idea by selective ablation of the components of the ovary at the beginning of seasonal quiescence in September and studied the subsequent fate of the embryos after the summer solstice in December.

Hearn $(1972,1973,1974)$ showed that seasonal quiescence is not associated with reduced gonadotrophin concentrations, as in true anoestrus, but results from a tonic inhibition of the corpus luteum by the pituitary, which can be released by hypophysectomy. Quiescence after hypophysectomy can be extended by treatment with ovine prolactin and Tyndale-Biscoe \& Hawkins (1977) concluded that prolactin is probably the pituitary inhibitor. However, Hearn, Short \& Baird (1977) suggested that an additional factor might be a seasonal change in 
hypothalamic sensitivity to ovarian feedback. The second objective of this study was therefore to examine the pituitary response to deprivation of the various ovarian components during seasonal quiescence by measuring luteinizing hormone $(\mathrm{LH})$ concentrations in peripheral plasma from the time of operation until after the summer solstice.

\section{Materials and Methods}

The animals were taken from a breeding colony of tammar wallabies derived from Kangaroo Island stock and maintained in Canberra. They were held in open grassy yards and provided with supplementary lucerne hay and oats. The females selected for the experiments were all adult and were post-lactational or near the end of lactation. The young were removed from the lactating females at the start of the project. The ovaries were exposed by mid-line laparotomy under pentobarbitone sodium anaesthesia. The ovary bearing the quiescent corpus luteum was noted and either this ovary alone (Group 3, Table 1) or both ovaries (Group 2) were removed by cautery at the hilus. In another group of bilaterally ovariectomized females (Group 4) the dark brown interstitial tissue and corpus luteum were dissected away and the pale coloured pieces of cortex of both ovaries returned to subcutaneous pockets in the pouch region. The skin of the pouch is thin and translucent so that the progress of the ovarian grafts could be followed by direct observation. After recovery from surgery the animals were returned to open yards, isolated from males and were examined and bled once a month until December and then more frequently. From Jnauary they were examined daily for birth and post-partum oestrus. Blood samples were collected from the lateral tail vein and the plasma stored at $-20^{\circ} \mathrm{C}$ until assay.

In late January or early February, when intact control animals (Group 1) gave birth, all except one group of experimental animals (Group 2b) were killed and the urogenital tracts and ovarian grafts were dissected out. Both uteri were flushed with saline $(9 \mathrm{~g} \mathrm{NaCl} / 1)$ to recover embryos or unfertilized eggs. Ovaries, grafts and uteri were fixed in Bouin's fluid, sectioned at 7 $\mu \mathrm{m}$ and stained with Heidenhain's iron haematoxylin and eosin.

The surviving group of bilaterally ovariectomized animals (Group 2b) was held until April when each animal was given a daily injection (i.m.) of $20 \mathrm{mg}$ progesterone in oil for 10 days. This treatment induces blastocyst reactivation in intact females during seasonal quiescence (Berger \& Sharman, 1969; Renfree \& Tyndale-Biscoe, 1973). No controls could be used because intact animals reactivate spontaneously at this time of year. These animals were killed at the end of April and examined in the same way as the other animals.

\section{Hormone assay}

LH was measured by heterologous radioimmunoassay described in detail by Hodges (1978) and based on the assay for rat LH reported by Welschen et al. (1975). The system used NIAMDD rat LH-I-1 for iodination, NIAMDD rat LH-RP-1 as standard and rabbit antiovine LH 610V (Uillenbroek) as antiserum.

All incubations were carried out in duplicate. Standards, test samples and ${ }^{125}$ I-labelled LH were diluted in $0.01 \mathrm{M}$-phosphate buffer ( $\mathrm{pH} \mathrm{7.5)} \mathrm{containing} \mathrm{1 \%} \mathrm{BSA.} \mathrm{Standards} \mathrm{were} \mathrm{diluted} \mathrm{in}$ buffer to enable the required amount of hormone to be dispensed in volumes of $200 \mu \mathrm{l}$. Plasma samples of $100 \mu \mathrm{l}$ were diluted in buffer to $200 \mu \mathrm{l}$. Antiserum $(100 \mu \mathrm{l}$ in $0.01 \mathrm{M}$-phosphate buffer containing $0.05 \mathrm{M}$-EDTA and $0.3 \%$ normal rabbit serum) was then added. The tubes were well shaken and allowed to incubate for 3 days at $4{ }^{\circ} \mathrm{C}$. The antiserum, at an initial dilution of $1: 70000$, bound $23-30 \%$ of labelled tracer $(n=15) .{ }^{125}$ I-Labelled LH (approximately 10000 c.p.m.) in $100 \mu \mathrm{l}$ buffer was added to all tubes which were shaken and incubated for a further 2 days at $4^{\circ} \mathrm{C}$. Separation of antibody-bound and free hormone was achieved by adding $200 \mu \mathrm{l}$ donkey anti-rabbit gamma globulin (Burroughs Wellcome RD-17 diluted 1:30 in 0.01 
M-phosphate buffer) and incubation was continued at $4^{\circ} \mathrm{C}$ for $12 \mathrm{~h}$. Phosphate buffer $(1 \mathrm{ml} 0.01$ $\mathrm{M}, \mathrm{pH} 7.5$ ) was added to each tube immediately before centrifugation at $500 \mathrm{~g}$ for $30 \mathrm{~min}$ at $4^{\circ} \mathrm{C}$. The supernatant was discarded and the antibody-bound ${ }^{125} \mathrm{I}$-labelled $\mathrm{LH}$ in the precipitate was measured in an automatic gamma counter.

The limit of detection in this system was $1.0 \mathrm{ng} / \mathrm{ml}$ with an intra-assay variation level between replicates of $3.5 \%$ and an interassay variation of $8 \%$. Because there was no standard preparation of wallaby $\mathrm{LH}$ available, the assay was validated biologically with plasma from intact, ovariectomized and hypophysectomized wallabies. LH concentrations were 1.1-3.4 $\mathrm{ng} / \mathrm{ml}$ (mean $2.3 \mathrm{ng} / \mathrm{ml}, n=25$ ) in intact females, $3.0-7.3 \mathrm{ng} / \mathrm{ml}$ (mean $5.7 \mathrm{ng} / \mathrm{ml}, n=12$ ) in ovariectomized females 4-6 months after removal of the ovaries, and below the detection limit of the assay in 15 hypophysectomized wallabies.

\section{Results}

\section{Group 2: bilateral ovariectomy}

Of the 9 females bilaterally ovariectomized 8 were pregnant but in none did pregnancy go to term (Table 1). Each of the 4 examined in early February (Group 2a), at the time when the controls (Group 1) gave birth, had a quiescent blastocyst of normal appearance (shell diameter $280 \pm 36$ (s.d.) $\mu \mathrm{m}$ ). The uteri of these 4 animals were intermediate in size and glandular development between those of intact females during seasonal quiescence and those of females hypophysectomized for 60 days (Table 2).

Table 1. Responses in ovary and embryo to deprivation of corpus luteum and interstitial tissue, and of the embryo to bilateral ovariectomy performed in tammar wallabies during seasonal quiescence

\begin{tabular}{|c|c|c|c|c|c|c|c|c|c|c|c|}
\hline \multirow[b]{3}{*}{ Group } & \multirow{3}{*}{$\begin{array}{l}\text { Treatment } \\
\text { in September }\end{array}$} & \multirow{3}{*}{$\begin{array}{c}\text { Autopsy } \\
\text { (month) }\end{array}$} & \multirow{3}{*}{$\begin{array}{l}\text { No. of } \\
\text { females }\end{array}$} & \multirow{2}{*}{\multicolumn{3}{|c|}{ Ovarian response }} & \multicolumn{5}{|c|}{ Embryo response } \\
\hline & & & & & & & & & Collapsed & & \\
\hline & & & & None & GF & $\mathrm{CL}$ & NP & QB & vesicle & Fetus & Birth \\
\hline \multirow{3}{*}{$\begin{array}{l}1 \\
2 \mathrm{a} \\
2 \mathrm{~b}\end{array}$} & Intact & February & 5 & - & - & 5 & 2 & - & - & - & 3 \\
\hline & Bilateral ovariectomy & February & 4 & 4 & - & - & - & 4 & - & - & - \\
\hline & $\begin{array}{l}\text { Bilateral ovariectomy } \\
+ \text { progesterone in } \\
\text { April }\end{array}$ & April & 5 & 5 & - & - & 1 & 1 & 3 & - & - \\
\hline \multirow[t]{2}{*}{3} & Unilateral ovariectomy & February & 9 & 3 & - & $\bar{c}$ & - & 3 & - & - & - \\
\hline & & & & $\overline{2}$ & - & 0 & 2 & $\overline{3}$ & 1 & 2 & 1 \\
\hline \multirow[t]{2}{*}{4} & Bilateral ovariectomy & February & 10 & 3 & $\overline{3}$ & - & $\overline{1}$ & $\begin{array}{l}3 \\
1\end{array}$ & $\overline{1}$ & - & - \\
\hline & plus cortex graft & & & 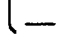 & - & 4 & 1 & - & - & 3 & - \\
\hline
\end{tabular}

$\mathrm{CL}=$ corpus luteum or luteinized follicle in graft; $\mathrm{GF}=$ Graafian follicle in ovary or graft; $\mathrm{NP}=$ not pregnant; $\mathrm{QB}=$ quiescent blastocyst.

Table 2. Uterine gland diameter and cell height, and uterine epithelium cell height of tammars in lactational quiescence, and seasonal quiescence, and after bilateral ovariectomy or hypophysectomy

\begin{tabular}{|c|c|c|c|c|}
\hline \multirow[b]{2}{*}{ Condition } & \multirow{2}{*}{$\begin{array}{c}\text { No. } \\
\text { of } \\
\text { females }\end{array}$} & \multicolumn{2}{|c|}{ Uterine gland } & \multirow{2}{*}{$\begin{array}{l}\text { Uterine epithelium } \\
\text { cell height }(\mu \mathrm{m})\end{array}$} \\
\hline & & Diameter $(\mu \mathrm{m})$ & Cell height $(\mu \mathrm{m})$ & \\
\hline $\begin{array}{l}\text { Lactational quiescence } \\
\text { Seasonal quiescence }\end{array}$ & $\begin{array}{l}3 \\
3\end{array}$ & $\begin{array}{l}89 \pm 4.6(70-120) \\
97 \pm 3.2(76-108)\end{array}$ & $\begin{array}{l}30 \pm 2 \cdot 6(18-50) \\
34 \pm 1 \cdot 3(22-41)\end{array}$ & $\begin{array}{l}27 \pm 1.2(20-35) \\
25 \pm 0.4(22-27)\end{array}$ \\
\hline $\begin{array}{l}\text { Bilaterally } \\
\quad \text { ovariectomized for } 4 \text { months }\end{array}$ & 4 & $57 \pm 5 \cdot 0(40-74)$ & $17 \pm 2 \cdot 0(13-25)$ & $19 \pm 2 \cdot 6(9-28)$ \\
\hline $\begin{array}{l}\text { Hypophysectomized } \\
\text { for } 2 \text { months }\end{array}$ & 3 & $28 \pm 1 \cdot 5(20-41)$ & $5 \pm 0.2(5-8)$ & $6 \pm 0.3(5-8)$ \\
\hline
\end{tabular}


The 5 females in Group 2b did not give birth in February or show any sign of pouch development associated with parturition. At autopsy in April, after treatment with progesterone, 4 had abnormal blastocysts, 3 of which were larger than quiescent blastocysts but were collapsed. Spermatozoa were visible in the mucin layer of all 4 blastocysts and it is unlikely that any of these blastocysts had undergone normal reactivation because spermatozoa and the mucin layer normally disappear by 9 days after reactivation.

\section{Group 3: unilateral ovariectomy}

The quiescent corpus luteum was removed but the animals retained interstitial and cortical tissue in the remaining ovary. At autopsy in January 6 of the 9 animals had ovulated (Table 1), and there was an active $C L$ in the ovary contralateral to the uterus containing the embryo. The other 3 females had neither CL nor Graafian follicles in the remaining ovary, but the uterus contralateral to the ovary contained a quiescent blastocyst of normal appearance (shell diameter $260 \pm 20 \mu \mathrm{m}$ ). Of the 6 females that ovulated, 4 were pregnant and the embryos had reactivated; one had a collapsed vesicle, two had advanced, normal embryos in the contralateral uterus and one female gave birth at the end of January, at the same time as the controls.

\section{Group 4: bilateral ovariectomy with cortex graft}

At autopsy in January or February the grafts were vascularized and well developed in 8 of the 10 animals and in 7 Graafian follicles or luteinized follicles had developed (Table 1). As in the unilaterally ovariectomized females, the 3 females without luteinized tissue or Graafian follicles had normal quiescent blastocysts in their uteri, while the 3 pregnant females with luteal tissue had normal developing embryos at the stage of mid-pregnancy. Of the 3 females with grafts containing enlarged follicles but no luteal tissue, one had a collapsed blastocyst, one a quiescent blastocyst and the third was not pregnant. The fate of blastocysts in females with grafts was therefore very similar to that in unilaterally ovariectomized females, which suggests that interstitial tissue does not contribute to embryo survival or development.

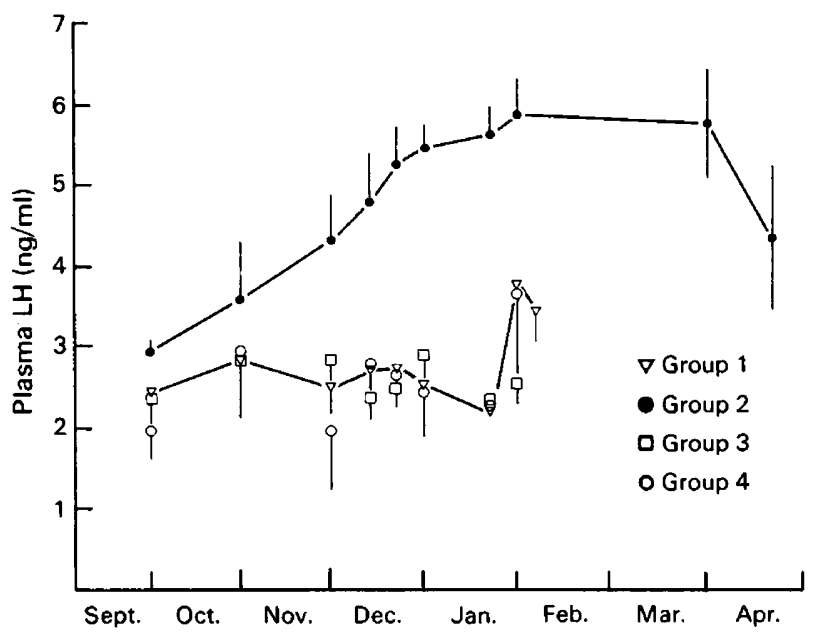

Text-fig. 1. Mean \pm s.e.m. concentrations of $\mathrm{LH}$ in peripheral plasma of female tammars during seasonal quiescence (October-December) and during reactivation in January. At the end of September, females were left intact $(\nabla$, Group 1$)$, bilaterally ovariectomized ( $($, Group 2$)$, unilaterally ovariectomized ( $\square$, Group 3 ), or bilaterally ovariectomized and cortical tissue replaced by grafting ( $O$, Group 4$)$. 


\section{LH concentrations}

In the intact and the unilaterally ovariectomized females (Groups 1 and 3) plasma LH remained steady at $2-3 \mathrm{ng} / \mathrm{ml}$ throughout the whole period from September to February (Text-fig. 1). In the bilaterally ovariectomized females (Group 2) there was no significant change at 1 month after operation but the LH levels steadily increased from 1 December to 1 February and were significantly higher than those of the controls on and after 23 December ( $t$ test, $P<$ $0.01)$. Values were still high on 5 April $(5.70 \pm 1.41 \mathrm{ng} / \mathrm{ml})$ and were not significantly depressed on 26 April after the progesterone treatment. In Group 4 females LH concentrations were indistinguishable from those of Groups 1 and 3. Only one female had an elevated level of $8 \cdot 3$ $\mathrm{ng} / \mathrm{ml}$ on 29 January when the graft contained 5 follicles and no luteal tissue, and it is possible that this was part of the preovulatory $\mathrm{LH}$ peak as described by Sutherland, Evans \& Tyndale-Biscoe (1980).

\section{Discussion}

The tammar blastocyst normally survives in diapause for 11 months in the intact female (Berger, 1966) and the present results demonstrate that, for the last 4 months of this period at least, its survival does not depend on any part of the ovary being present. Indeed, blastocyst survival was better in bilaterally ovariectomized females and in those in which the ovarian grafts failed to take than in those which retained non-luteal ovarian tissue. The failure of blastocysts to reactivate normally at 15 months post coitum when the mothers were treated with progesterone suggests that, although not yet dead, the blastocysts were by then no longer capable of normal development. Since the size and condition of the uteri of bilaterally ovariectomized females more nearly resembled those of intact quiescent females than those of hypophysectomized females, it is possible that they were maintained by progesterone from the adrenal cortex. Sernia, Hinds \& Tyndale-Biscoe (1980) observed no difference in plasma concentrations, production rate or metabolic clearance of progesterone between intact quiescent and ovariectomized female tammars. Since the uteri of females 2 months after hypophysectomy became quite regressed and similar to those of anoestrous quokkas (see Sharman \& Berger, 1969), the elevated pituitary gonadotrophin secretion after bilateral ovariectomy may have stimulated the adrenal cortex to secrete progesterone and compensate for the ovaries. Vinson \& Renfree (1975) have provided evidence that exogenous gonadotrophin caused elevation of plasma androgen in ovariectomized opossums, presumably by secretion from the adrenal cortex.

Although the ovaries are not essential for blastocyst maintenance the results clearly show that reactivation leading to normal development of the embryo is dependent on the presence of luteal tissue, whether it be by ovulation in the remaining ovary or by luteinization of the membrana granulosa of follicles developed in an ovarian graft. The latter results indicate that the stimulus is a systemic one and not due to a local transfer from the CL to the adjacent uterus.

No essential role for the interstitial tissue in blastocyst maintenance or reactivation emerges from the results and the initial postulate, based on a comparison with the quokka, is not sustained. Furthermore, the interstitial tissue is not necessary for luteinization to occur or for ovarian negative feedback on pituitary secretion of $\mathrm{LH}$. This latter point has been more fully substantiated by Evans, Tyndale-Biscoe \& Sutherland (1980) who showed that the negative feedback applies to FSH as well as to LH.

In the present study with lactationally quiescent females the pituitary response to bilateral ovariectomy developed more slowly than in females ovariectomized during the breeding season (Evans et al., 1980), when elevation of LH occurred 2 weeks after ovariectomy, and this suggests that there may be seasonal differences in hypothalamic sensitivity to ovarian inhibition, as suggested by Hearn et al. (1977) 


\section{References}

Berger, P.J. (1966) Eleven-month "embryonic diapause" in a marsupial. Nature, Lond. 211, 435-436.

Berger, P.J. \& Sharman, G.B. (1969) Embryonic diapause initiated without the suckling stimulus in the wallaby, Macropus eugenii. J. Mammal. 50, 630632.

Evans, S.M., Tyndale-Biscoe, C.H. Sutherland, R.L. (1980) Control of gonadotrophin secretion in the female tammar wallaby (Macropus eugenii). $J$. Endocr. 86, 13-24.

Hearn, J.P. (1972) The development of a radioimmunoassay for gonadotrophin in the tammar wallaby, Macropus eugenii. J. Reprod. Fert. 28, 132, Abstr.

Hearn, J.P. (1973) Pituitary inhibition of pregnancy. Nature, Lond. 241, 207-208.

Hearn, J.P. (1974) The pituitary gland and implantation in the tammar wallaby, Macropus eugenii. J. Reprod. Fert. 39, 235-241.

Hearn, J.P., Short, R.V. \& Baird, D.T. (1977) Evolution of the luteotrophic control of the mammalian corpus luteum. In Reproduction and Evolution, pp. 255264. Eds J. H. Calaby \& C. H. Tyndale-Biscoe. Australian Academy of Science, Canberra.

Hodges, J.K. (1978) Effects of gonadectomy and oestradiol treatment on plasma LH concentrations in the marmoset monkey, Callithrix jacchus. J. Endocr. 76, 271-281.

Renfree, M.B. \& Tyndale-Biscoe, C.H. (1973) Intrauterine development after diapause in the marsupial, Macropus eugenii. Devl Biol. 32, 28-40.

Sadleir, R.M.F.S. \& Tyndale-Biscoe, C.H. (1977) Photoperiod and the termination of embryonic diapause in the marsupial Macropus eugenii. Biol. Reprod. 16, $605-608$.

Sernia, C., Hinds, L. \& Tyndale-Biscoe, C.H. (1980) Progesterone metabolism during embryonic diapause in the female tammar wallaby, Macropus eugenii. $J$. Reprod. Fert. 60, 139-147.

Sharman, G.B. (1955) Studies on marsupial reproduction. 3. Normal and delayed pregnancy in Setonix brachyurus. A ust. J. Zool. 3, 56-70.

Sharman, G.B. \& Berger, P.J. (1969) Embryonic diapause in marsupials. Adv. Reprod. Physiol. 4, 211-240.

Sutherland, R.L., Evans, S.M. Tyndale-Biscoe, C.H. (1980) Macropodid marsupial luteinising hormone: validation of assay procedures and changes in plasma levels during the oestrous cycle in the female tammar wallaby (Macropus eugenii). J. Endocr. 86, $1-12$.

Tyndale-Biscoe, C.H. \& Hawkins, J. (1977) The corpora lutea of marsupials: aspects of function and control. In Reproduction and Evolution, pp. 245-252. Eds J. H. Calaby \& C. H. Tyndale-Biscoe. Australian Academy of Science, Canberra.

Vinson, G.P. \& Renfree, M.B. (1975) Biosynthesis and secretion of testosterone by adrenal tissue from the North American opossum, Didelphis virginiana, and the effects of tropic hormone stimulation. Gen. comp. Endocr. 27, 214-222.

Welschen, R., Osman, P., Dullaart, J., de Greef, W.J., Uillenbroek, J. Th. J. \& de Jong, F.H. (1975) Levels of FSH, LH, oestradiol-17 $\beta$ and progesterone, and follicle growth in the pseudopregnant rat. J. Endocr. 64, 37-47.

Received 22 January 1981 